\title{
Prolonged Inhibitory Effect of Progesterone on Ovulation in the Domestic Hen (Gallus domesticus)
}

\author{
Noboru Saito, Norimichi Tsuzuki and Kiyoshi Shimada \\ Department of Animal Physiology, Faculty of Agriculture, Nagoya University, \\ Chikusa, Nagoya 464, Japan
}

Progesterone $\left(\mathrm{P}_{4}\right)$ as a positive feedback signal plays a pivotal role in the regulation of $\mathrm{LH}$ release occurring 4 to $6 \mathrm{hr}$ before ovulation in the laying hen. Injection of $\mathrm{LH}$ induces $\mathrm{P}_{4}$, and $\mathrm{P}_{4}$ injection induces $\mathrm{LH}$ release causing ovulation when those injections are made 8-10 hr before preovulatory $\mathrm{LH}$ release ${ }^{1 \sim 3)}$. $\quad \mathrm{P}_{4}$ may exert its stimulatory effect on the hypothalamus as well as other regions of the brain ${ }^{4 \sim 7}$.

Recently, negative feedback of steroid hormones in the regulation of $\mathrm{LH}$ release has been suggested ${ }^{8)}$. When $\mathrm{P}_{4}$ is injected shortly after ovulation, the next ovulation is delayed 2). In some, the ovary atrophies ${ }^{9}$. The present study was conducted to investigate the inhibitory effect of chronic administration of $\mathrm{P}_{4}$ on the regulatory mechanisms of preovulatory LH release and to examine at which level of the hypothalamo-anterior pituitary-ovarian axis $\mathrm{P}_{4}$ exerts the effect.

\section{Material and Methods}

\section{Animals}

Ninety crossbred laying hens (Goto 360, Goto Hatchery Inc. Japan), 10-14 months old and weighing 1.55-2.21 (averaging 2.01) $\mathrm{kg}$, were maintained in individual cages. The lighting regimen was $14 \mathrm{hr}$ light $(0600-2000) / 24 \mathrm{hr}$ and food and water were always available. The recording system for the time of oviposition was the same as previously report$\mathrm{ed}^{10)}$. The experimental hens laid relatively regular sequences of 5 to 8 eggs on consecutive days in a sequence and each sequence was separated by a pause day. Ovulation was considered to occur $30 \mathrm{~min}$ after oviposition of the previous ovum in the series ${ }^{11}$.

Design of Experiments

The present study consists of 4 experiments as summarized in Fig. 1. Before the initiation of the study, $5 \mathrm{~cm}$ sections of Silastic tubing (i.d. $2.64 \mathrm{~mm}$, Corning Co. NY.) filled with $\mathrm{P}_{4}$ crystal powder (Sigma Co. St. Louis) was implanted under the abdominal skin of hens. Two days after the implantation the Silastic tubing was removed and stored at $-20^{\circ} \mathrm{C}$. Hens used for pretreating of the Silastic tubes were not used in any of the 4 experiments. The time of ovulation was determined by the position of the ovum in the oviduct at autopsy (Fig. 1).

\section{Experiment 1}

Two Silastic tubings filled with progesterone $(\mathrm{Pt})$ were implanted under the abdominal skin of each hens $1.5 \mathrm{hr}$ after the second $\left(\mathrm{C}_{2}\right)$ ovulation of the sequence $\left(24 \mathrm{hr}\right.$ before $\mathrm{C}_{3}$ ovulation). Seven and $18 \mathrm{hens}$ were killed by overdose of pentobarbital sodium at $45 \mathrm{hr}$ and 


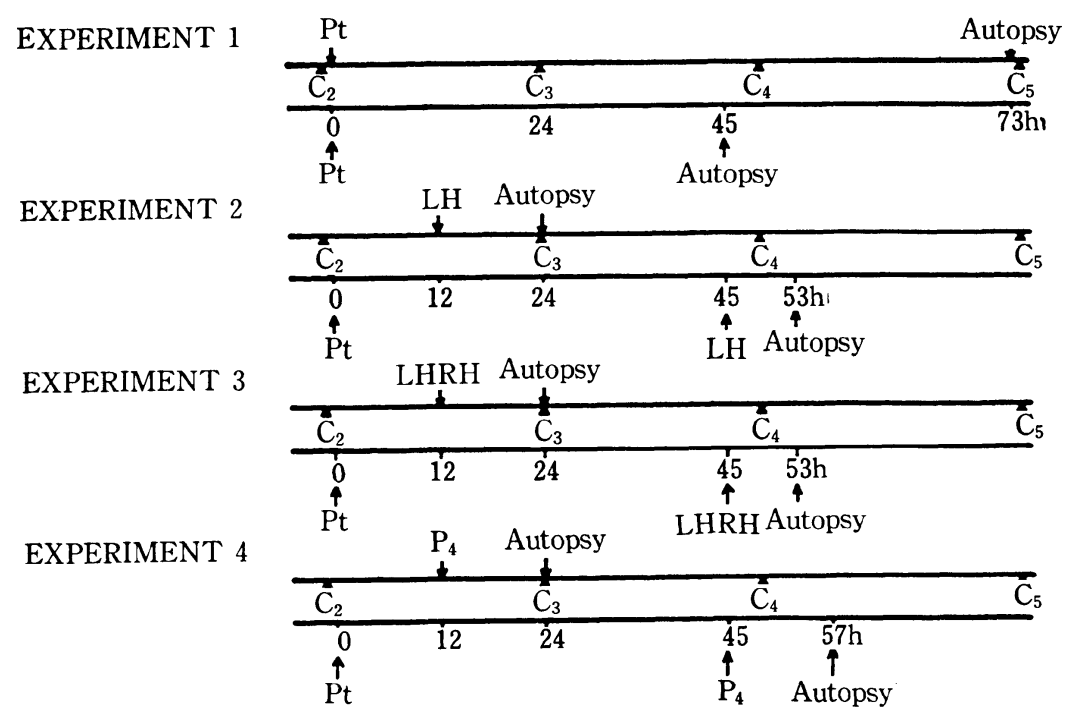

Fig. 1. Schematic illustration of the experimental protocols. Progesterone filled in the Silastic tubing $(\mathrm{Pt})$ was implanted s. c. $1.5 \mathrm{hr}$ after the second ovulation $\left(\mathrm{C}_{2}\right)$ of a sequence. $\mathrm{C}_{3}, \mathrm{C}_{4}$ and $\mathrm{C}_{5}$ designate subsequent, expected ovulations of third, fourth and fifth eggs of the sequence, respectively. Numbers of $h$ in dicate time (hr) after $\mathrm{Pt}$ implantation. Treatments were shown above and below each panel, respectively, for Experiments 2, 3 and 4 .

$73 \mathrm{hr}$ after Pt implantation, respectively.

\section{Experiment 2}

One hundred micrograms of ovine $\mathrm{LH}$ (NIH-LH-S24) in $0.5 \mathrm{ml} \mathrm{NaCl}(9 \mathrm{~g} / 1)$ solution was given intraperitoneally $\left.{ }^{12}\right) 45 \mathrm{hr}$ after $\mathrm{Pt}$ implantation in 13 hens as described in Experiment 1. Another 13 hens were injected $13.5 \mathrm{hr}$ after $\mathrm{C}_{2}$ ovulation (12 hr before $\mathrm{C}_{3}$ ovulation with $\mathrm{LH}$ but received no $\mathrm{Pt}$ treatment. The hens with $\mathrm{Pt}$ were killed $8 \mathrm{hr}$ after injection but hens without $\mathrm{Pt}$ were killed $12 \mathrm{hr}$ after the injection.

\section{Experiment 2}

Ten hens were injected intramuscularly with $\left[\mathrm{Arg}^{8}\right]-\mathrm{LHRH}(25 \mu \mathrm{g} / \mathrm{hen}$, Peptide Institute Protein Research Foundation) in $0.5 \mathrm{ml} \mathrm{NaCl}$ solution $45 \mathrm{hr}$ after Pt treatment as described in Experiments 1 and 2. Another 10 hens without Pt were given only LHRH 13.5 hr after $\mathrm{C}_{2}$ ovulation.

\section{Experiment 3}

Eleven hens were injected with Progesterone $(1.0 \mathrm{mg} /$ hen, Oophormin Luteum, Teikokuzoki Pharmaceutical Co.) into the breast muscle $45 \mathrm{hr}$ after implantation. Eight hens without pretreatment were injected $\mathrm{P}_{4}$ at $13.5 \mathrm{hr}$ after $\mathrm{C}_{2}$ ovulation.

\section{Plasma Collection and Radioimmunoassay of Plasma Steroids and LH}

The brachial vein was catheterized and in each hen blood samples were collected serially at $0,2,4,6$ and $45 \mathrm{hr}$ after Pt implantation in the Experiment 1 . In the Experiment 2, 3 and 4 blood was collected $0,1,2,3$ and $4 \mathrm{hr}$ after each injection of LH, LHRH or $\mathrm{P}_{4}$ in all hens whether or not they were pretreated wtih Pt. Usually $1.0-2.0 \mathrm{ml}$ blood was collected for each sample. Plasma samples were stored at $-20^{\circ} \mathrm{C}$ until use 
The concentrations of $\mathrm{P}_{4}$, testosterone $(\mathrm{T})$ and estradiol-17 $\beta\left(\mathrm{E}_{2}\right)$ in plasma were measured by antiserum against each steroid (Teikoku Zoki Pharmaceutical Co.) using radioimmunoassays $^{13,14)}$. The minimum detectable level was $25 \mathrm{pg} / \mathrm{m} l$ for $\mathrm{P}_{4}, \mathrm{~T}$ and $\mathrm{E}_{2}$. The intraand inter-assay coefficients of variation were 7.6 and $15.5 \%$ for $\mathrm{P}_{4}, 6.5$ and $13.8 \%$ for $\mathrm{T}$, and 7.4 and $19.0 \%$ for $E_{2}$, respectively.

Plasma concentrations of $\mathrm{LH}$ were measured one assay in duplicate using radioimmunoassay described by Hattori and Wakabayashi ${ }^{15}$. Rabbit anti-LH serum (Anti-AL-MH-\#1) and avian $\mathrm{LH}$ preparation (IEF-1) for raioiodination and standards were provided by Dr. K. Wakabayashi and Dr. M. Hattori, Gunma University. The minimum detectable level of $\mathrm{LH}$ was $0.1 \mathrm{ng} / \mathrm{ml}$ and intraassay coefficient variation (CV) was $10.3 \%$.

Statistical Analysis

Hormone data between Pt-treated and non-treated hens were compared by two-way analysis of variance (ANOVA). The mean values at different time within the same group were compared by Duncan's new mulitple range test after analysis of variance (ANOVA). The rates of induced ovulation between groups and induction time for ovulation between groups within each experiment were compared by $\chi^{2}$-test and by Student's $t$-test, respecti . vely.

\section{Results}

Effects of Pt Implantation on Spontaneous Ovulation and Plasma Concentrations of LH, $P_{4}, T$ and $F_{2}$

An autopsy at $73 \mathrm{hr}$ after Pt treatment revealed that no ovulation took place until $65 \mathrm{hr}$ from the treatment in the total 18 hens: 8 hens ovulated $67.5 \pm 1.1 \mathrm{hr}$ (mean \pm s. e. m.) after the treatment and 10 hens did not ovulate up to the autopsy time. Two of the latter 10 hens showed a sign of the "bursting" atresia of the ovarian follicles. All the hierarchical yellow follicles of the ovary gained more weight as the time elapsed after Pt treatment in compa. rison to follicle weight of hens without Pt. The first, second and third largest preovulatory follicles (F1, F2 and F3) $73 \mathrm{hr}$ after Pt treatment showed 102, 100 and 87\% weight of the ovum ovulated a day before the Pt implant (average weight \%, $\mathrm{N}=7$ ). The weight of $\mathrm{F} 1$, F2 and F3 $45 \mathrm{hr}$ after Pt treatment was 96, 83 and $65 \%$ of the previously shed ovum while the weight of those follicles of hens without $\mathrm{Pt} 13.5 \mathrm{hr}$ after $\mathrm{C}_{2}$ ovulation showed 92, 79 and $54 \%$, respectively.

Figure 2 illustrates the changes in plasma concentrations of $\mathrm{LH}, \mathrm{P}_{4}, \mathrm{~T}$ and $\mathrm{E}_{2}$ up to 45 $\mathrm{hr}$ after Pt treatment in hens which did not ovulate. The plasma $\mathrm{P}_{4}$ concentrations markedly increased soon after $\mathrm{Pt}$ treatment and remained high throughout the period $(\mathrm{P}<0.01)$. Plasma LH concentrations increased significantly $4 \mathrm{hr}$ after $\mathrm{Pt}$ treatment $(\mathrm{P}<0.01)$ followed by a significant decrease $(\mathrm{P}<0.01) 45 \mathrm{hr}$ after the treatment as compared to the pretreatment levels. Plasma $\mathrm{T}$ and $\mathrm{E}_{2}$ concentrations also rose for the $2 \mathrm{hr}$ and then decreased. Significantly lower levels, however, were detected at $45 \mathrm{hr}(\mathrm{P}<0.01)$.

Effect of LH Injection on Ovulation

The foregoing results may suggest either that the preovulatory LH surge is not released or that the ovary aose not respond to spontaneous preovulatory LH surge. Accordingly, LH was injected to test the responsiveness of the ovarian follicle. As shown in Table 1, the in- 


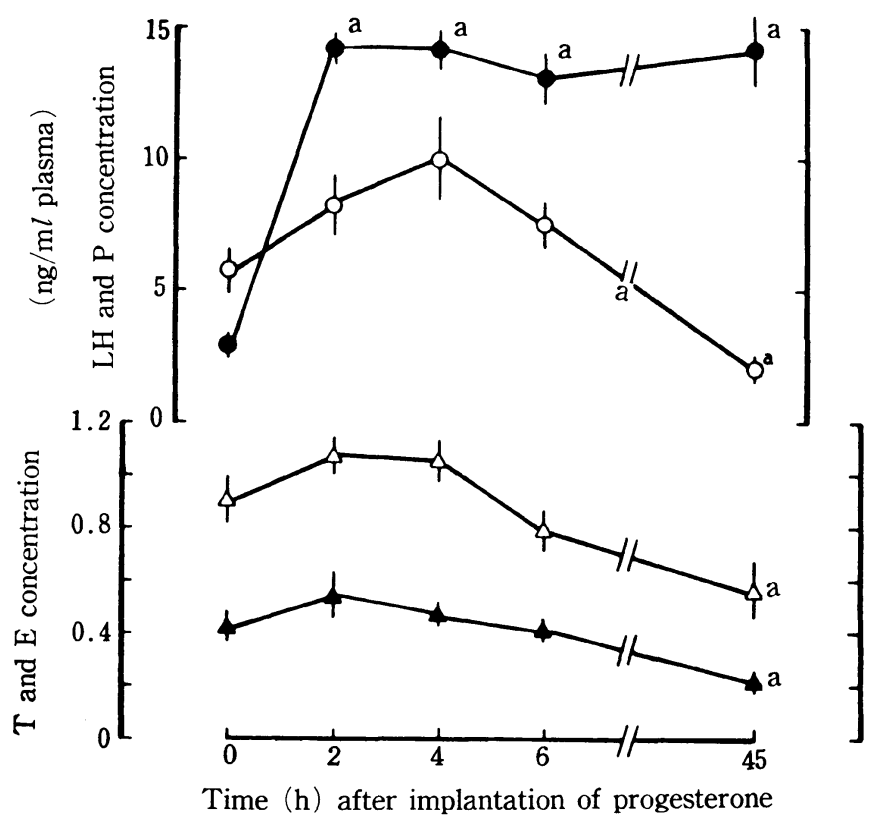

Fig. 2. Time course changes in plasma concentrations of LH (open circle), progesterone (closed circle), testosterone (open triangle) and estradiol (closed triangle) after implantation of Pt. Vertical lines indicate s.e.m. "a" indicate a significant difference from pretreatment levels at $\mathrm{P}<0.01$. $\mathrm{n}=7$ hens.

Table 1. Effect of $\mathrm{Pt}$ pretreatment on LH-, LHRH- and P- induced ovulation

\begin{tabular}{cccc}
\hline Treatment & $\begin{array}{c}\text { Number of Hens } \\
\text { Injected }\end{array}$ & $\begin{array}{c}\text { Number of Hens } \\
\text { Ovulating }\end{array}$ & $\begin{array}{c}\text { Interval* between } \\
\text { Injection and } \\
\text { Ovulation (h) }\end{array}$ \\
\hline Experiment 2 & 13 & 9 & $8.8 \pm 0.9$ \\
LH only & 13 & 9 & $6.0 \pm 0.4$ \\
Pt+LH & 10 & 6 & $8.4 \pm 0.3$ \\
Experiment 3 & 10 & 8 & $4.7 \pm 0.4$ \\
LHRH only & & 6 & $8.6 \pm 0.3$ \\
Pt+LHRH & 8 & 3 & $4.0^{+}, 8.4^{+}, 10.5^{+}$ \\
Experiment 4 & 11 & 6 & \\
P only & & 6 & \\
\hline
\end{tabular}

$\mathrm{P}$ and $\mathrm{Pt}$ indicate progesterone suspended in oil and progesterone in the Silastic tubings, respectively.

*, Intervals between injection and ovulation, are means \pm s. e. m. in hens which ovulated before the autopsy time. The values with different superscripts (a, b) indicate a significant difference within each experiment (Student's $t$-test, $\mathrm{P}<0.01$ ).

+ , individual values.

duced-ovulation by $\mathrm{LH}$ injection in hens with $\mathrm{Pt}$ was the same rate as in hens without Pt. It is noted that the induction time was significantly shorter in hens with Pt implant than in hens without it $(\mathrm{P}<0.01)$.

Effect of LHRH Injection on Ovulation

LHRH was injected to test the responsiveness of the anterior pituitary. There was no 
significant difference in the rates of induced ovulation between the hens with and without $\mathrm{Pt}$ (Table 1). The induction time was significantly shorter in those hens with $\mathrm{Pt}$ than in hens without $\mathrm{Pt}(\mathrm{P}<0.01)$.

\section{Effect of $P_{4}$ Injection on Ovulation}

Since the anterior pituitary gland responded to exogenous LHRH, $\mathrm{P}_{4}$ was injected to study the responsiveness of the hypothalamus or other parts of CNS. In hens without $\mathrm{Pt}$ implantation, ovulation was induced in 6 of the 8 hens by $\mathrm{P}_{4}$ injection and the inducedovulation occurred at about the same rate as $\mathrm{LH}$ and $\mathrm{LHRH}$ injection. In contrast, in hens with $\mathrm{Pt}$ treatment ovulation was induced only in 3 hens and was not induced in other 8 hens $P_{4}$ injection.

\section{Effect of LH Injection on Plasma Concentrations of $L H, P_{4}$ and $T$}

Since there were considerable differences in $\mathrm{LH}, \mathrm{P}_{4}$ and $\mathrm{T}$ plasma levels at the time of $\mathrm{LH}$ injection between hens with and without $\mathrm{Pt}$ treatment. The hormone concentrations in plasma were expressed as the increment of the concentration after subtracting the prein-

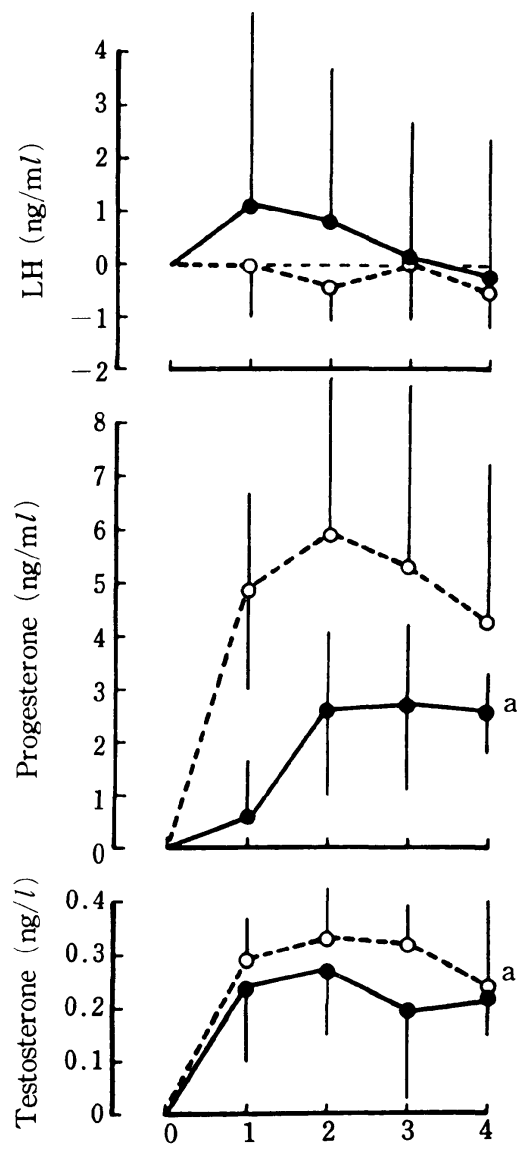

Time (h) after LH injection

Fig. 3. Increment of plasma concentrations of LH, progesterone and testosterone in response to $\mathrm{LH}$ injection in hens with either non-treated (closed circle) or treated (open circle) with Pt. In this subsequent figures, " a " indicate a significant difference from preinjection levels at $\mathrm{P}<0.01 . \mathrm{n}=5$ hens. 
jection value from the value at any given time. The hormone concentrations were measusred only in hens which were induced ovulation by injection.

In hens subjected to LH injection without Pt treatment, there was no significant effect of LH injection on plasma LH concentrations (Fig. 3). Plasma $\mathrm{P}_{4}$ concentrations significantly increased $2 \mathrm{hr}$ after the injection and high levels were maintained. T levels rapidly increased and reached the plateau level $1 \mathrm{hr}$ after the injection.

In hens with Pt implant, there was no difference of $L H$ levels but plasma $\mathrm{P}_{4}$ levels showed a faster increase when compared to hens without $\mathrm{Pt}$ treatment and the $\mathrm{P}_{4}$ increments in $\mathrm{Pt}$ treated hens were significantly larger than the hens without $\mathrm{Pt}(\mathrm{P}<0.01)$. T concentrations in both groups increased significantly from preinjection levels $(P<0.01)$.

Effect of LHRH Injection on Plasma Concentrations of LH, $P_{4}$ and T

Fig. 4 illustrates the time course changes in the increment of plasma LH, $\mathrm{P}_{4}$ and $\mathrm{T}$ concentrations after LHRH injection. Plasma LH concentrations in hens without Pt markedly increased and attained a peak at $2 \mathrm{hr}$ after the injection. In the Pt-treated hens, LH
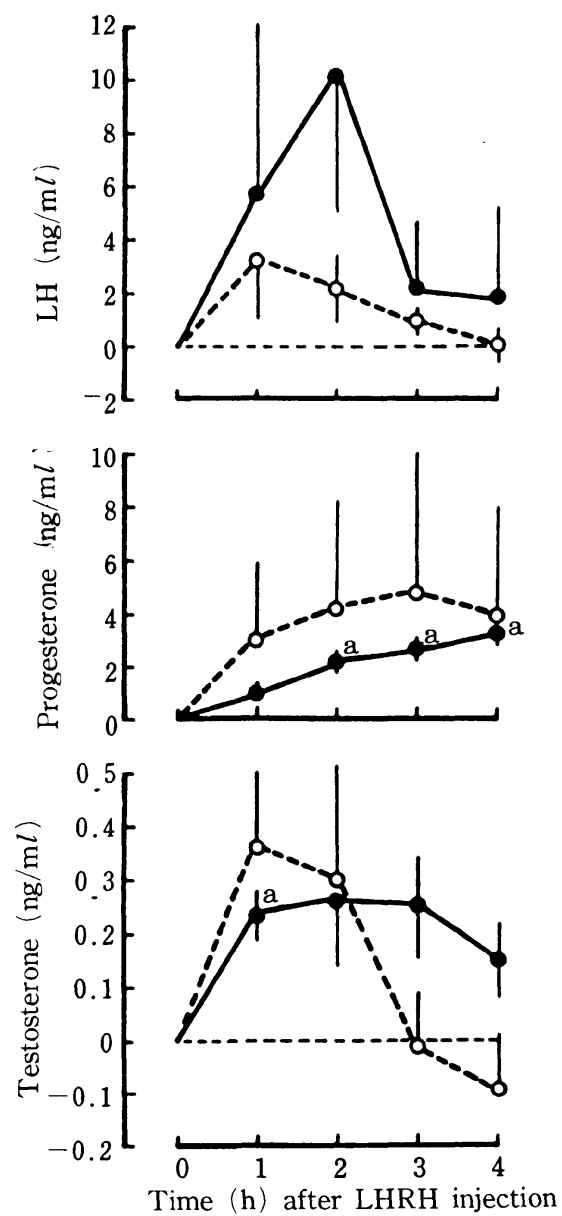

Fig. 4. Increment of plasma concentrations of $\mathrm{LH}$, progesterone and testosterone in response to LHRH injection in hens with either non-treated (closed circle) or treated (open circle) with Pt. $\mathrm{n}=5$ hens. 
increment was less prominent. The difference in the $\mathrm{LH}$ increment between two groups was significant $(P<0.05)$. Plasma $\mathrm{P}_{4}$ concentrations significantly increased in hens without $\mathrm{Pt}$ after LHRH injection. Pt-treated hens showed higher levels of $\mathrm{P}_{4}$ than non-treated hens $(\mathrm{P}<0.05)$. Significantly higher levels of $\mathrm{T}$ were also maintaind in non-treated hens whereas increased $\mathrm{T}$ concentrations immediately after the injection started decreasing $3 \mathrm{hr}$ after the injection in hens with Pt treatment, which possibly corresponded to the latter half of the ovulation process (Table 1 ).

\section{Effect of $P_{4}$ Injection on Plasma Concentrations of LH, $P_{4}$ and T}

In hens with and without Pt, there was no significant increase in plasma concentrations of $\mathrm{LH}$ or $\mathrm{T}$ at any time after $\mathrm{P}_{4}$ injection when compared to the respective preinjection levels (Fig. 5). On the other hand, the increment of plasma $\mathrm{P}_{4}$ concentration was marked $1 \mathrm{hr}$ after exogenous $\mathrm{P}_{4}$ injection and continued increasing in hens without $\mathrm{Pt}$. Greater $\mathrm{P}_{4}$ increment may be attributable, at least in a part, to exogenous origin. As mentioned above (Table 1), ovulation was provoked by the injection only 3 out of 11 hens pretreated with $\mathrm{Pt}$ and the induction time was so variable that $\mathrm{LH}$ and steroid levels were
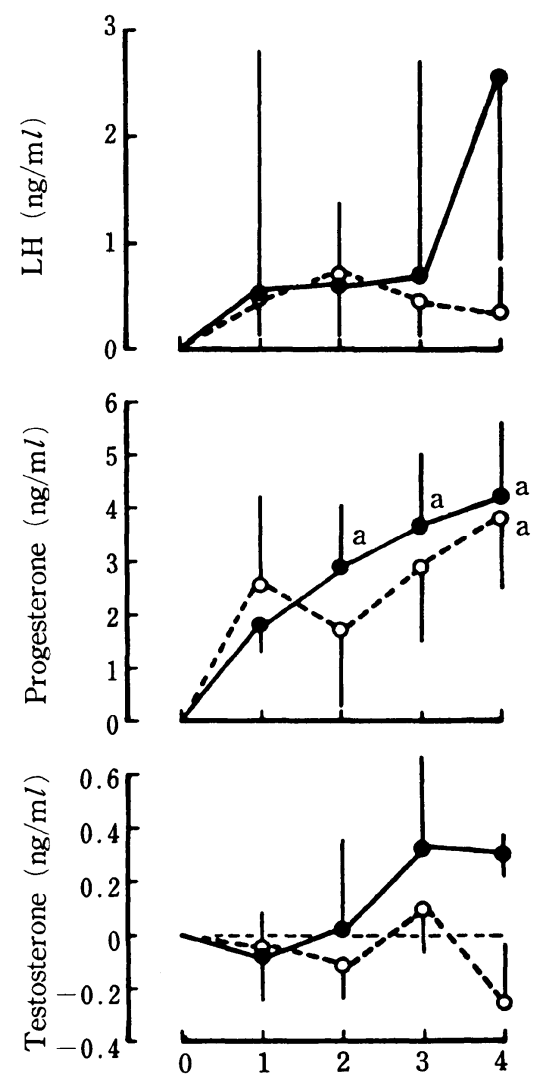

Time (h) after $\mathrm{P}$ injection

Fig. 5. Increment of plasma concentrations of LH, progesterone and testosterone in response to progesterone injection in hens with either non-treated (closed circle) or treated (open circle) with $\mathrm{Pt} . \mathrm{n}=5$ hens. 
measured only in hens which did not ovulate. There was no statistical difference in the $\mathrm{P}_{4}$ increments between the two groups.

\section{Discussion}

The present study demonstrated a prolonged inhibitory effect of continuous diffusion of $\mathrm{P}_{4}$ from Silastic tubing on ovulation in the chicken. The delay of spontaneous ovulation for $41 \mathrm{hr}$ reported here is much longer than that caused by a single $\mathrm{P}_{4}$ injection ${ }^{2}$. The delay may be attributable to lack of the preovulatory LH release. It is noted that basal $\mathrm{LH}$ levels were lowered $45 \mathrm{hr}$ after the treatment to below pretreatmert levels. Furthermore, the LH response to LHRH injection was significantly lower in the Pt-treated hens when compared to that in the non-treated hens, suggesting that exogenous $\mathrm{P}_{4}$ partly act at the pituitary level as a negative feedback signal. It seems unlikely that this apparent suppression of LH release is merely reflected upon the empty of the LH store in the pituitary gland because the anterior pituitary seems capable of restoring $\mathrm{LH}$ production a few hours after stimulation according to WILSON and SHARP ${ }^{1)}$. They demonstrated $\mathrm{LH}$ release by $\mathrm{P}_{4}$ injection at any time during the ovulatory cycle after the preovulatory $\mathrm{LH}$ surge (an intrinsic stimulation). Johnson et al. ${ }^{16)}$ also showed significant rises in plasma LH concentration which were $1 \mathrm{hr}$ apart in response to successive LHRH injections.

Among the steroid hormones in plasma, $\mathrm{P}_{\mathbf{4}}$ may serve as inhibitory signal in the regulation of the $\mathrm{LH}$ release because significantly higher levels were maintained throughout the experimental period. In contrast, $\mathrm{T}$ and $\mathrm{E}_{2}$ concentrations in plasma did not increase significantly but decreased to those below the pretreatment levels. These steroid changes may be reflected by the $\mathrm{LH}$ levels in plasma or directly inhibited by exogenous $\mathrm{P}_{4}$. Although an inhibitory effect of large dose of $\mathrm{E}_{2}$ on ovulations has been reported by FRAPS ${ }^{1 .}$, their result is not pertinent to this study. It seemed that $\mathrm{Pt}$ stimulated $\mathrm{LH}$ release soon after the implantation but it suppressed $\mathrm{LH}$ release later. The switch mechanism, if any, from a positive to an inhibitory signal remains unknown. Positive feedback actions of $\mathrm{P}_{4}$ is probably mediated by the hypothalamic $\mathrm{P}_{4}$ receptors ${ }^{18,19)}$. Prolonged treatment of $\mathrm{Pt}$ may alter characteristics of the hypothalamic $\mathrm{P}_{4}$ receptor but nothing is known about possible roles of the $\mathrm{P}_{4}$ receptor in relation to the negative feedback system.

Our data appear to support the idea that $\mathrm{P}_{4}$ may exert its effect on the hypothalamus as well as other regions of the CNS which are implicated in the regulation of the preovulatory LH surge. First, after Pt treatment, the ovary responded to the exogenous LH challenge by a significant increase in plasma $\mathrm{P}_{4}$ concentrations and the rate of induced ovulation was the same as that in hens without $\mathrm{Pt}$ treatment. In this case $\mathrm{LH}$ release might not be provoked by the rising levels of endogenous $\mathrm{P}_{4}$. Second, LHRH injection after $\mathrm{Pt}$ treatment also induced ovulation and the rate of the induced ovulation was larger than that in nontreated group. Although LH response was less prominent after LHRH stimulation in the Pt-treated hens when compared to that in hens without Pt treatment, it increased significantly $2 \mathrm{hr}$ after the injection $(\mathrm{P}<0.01)$, suggesting that the anterior pituitary is still responsive to its tropic hormone after $\mathrm{Pt}$ treatment. Third, an injection of $\mathrm{P}_{4}$ in a dose sufficient to induce ovulation in intact hens failed to induce ovulation in the majority hens pretreated with $\mathrm{Pt}$ and no increase in plasma $\mathrm{LH}$ concentration was observed after $\mathrm{P}_{4}$ injection. 
Failure in inducing ovulation with $\mathrm{P}_{4}$ injection in $\mathrm{Pt}$-treated hens, on the other hand, may partly be attributable to modification of the ability of the hen after prolonged $\mathrm{Pt}$ treatments. Although the majority of Pt-treated hens did not ovulate in response to $\mathrm{P}_{4}$ injection, the $\mathrm{P}_{4}$ increments were not significanlly different from those in non-treated hens which ovulated after $\mathrm{P}_{4}$ injection. The high increaments of $\mathrm{P}_{4}$ levels in $\mathrm{Pt}$-treated hens may be resulted from exogenous $\mathrm{P}_{4}$ which half life might be prolonged by $\mathrm{Pt}$ treatment.

The shorter ovulation-induction time in hens pretreated with $\mathrm{Pt}$ in response to $\mathrm{LH}$ or LHRH injection was contrasted to hens without $\mathrm{Pt}$ treatment. The different responsiveness of the ovary to trophic hormones between hens with and those without $\mathrm{Pt}$ treatment may be explained not only by the more rapid release of endogenous $\mathrm{P}_{4}$ but also by higher levels of $\mathrm{P}_{4}$ in plasma after injections in hens with $\mathrm{Pt}$ than those without Pt.

The ovary after Pt treatment resembles that after PMSG treatment which disrupts the follicular hierarchy by enhancing growth of smaller follicles to the F1 size and leads to the cessation of ovulation ${ }^{20)}$. Recent studies on the effect of PMSG on plasma levels of LH and steroid hormones demonstrate that plasma concentrations of $\mathrm{P}_{4}$ and $\mathrm{E}_{2}$ increased whereas the LH levels decreased after PMSG injections ${ }^{8,21 \sim 23)}$. These studies suggests that $\mathrm{P}_{4}$ and $\mathrm{E}_{2}$ play a part in suppressing LH release after PMSG injections which delay spotaneous ovulations.

\section{Summary}

Progesterone in Silastic tubing $(\mathrm{Pt}$ ) was implanted subcutaneously $1.5 \mathrm{hr}$ after the second $\left(\mathrm{C}_{2}\right)$ ovulation of the sequence in the hen and effects of $\mathrm{Pt}$ treatment on subsequent ovulation and plasma concentrations of $\mathrm{LH}$, progesterone $\left(\mathrm{P}_{4}\right)$, testosterone $(\mathrm{T})$ and estradiol $\left(\mathrm{E}_{2}\right)$ were studied. Plasma concentrations of $\mathrm{P}_{4}$ increased rapidly about 5-fold and remained high throughout $45 \mathrm{hr}$ after Pt implantation. LH levels also significantly increased (1.4-fold) $4 \mathrm{hr}$ after $\mathrm{Pt}$ treatment but declined thereafter to levels below the pretreatment levels. $\mathrm{T}$ and $\mathrm{E}_{2}$ levels showed changes similar to $\mathrm{LH}$ levels but significant changes were detected only at 45 hr after the treatment. This treatment resulted in delayed ovulation for more than $41 \mathrm{hr}$. To examine the responsiveness of the hypothalamo-anterior pituitary-ovarian axis in those hens either ovine LH $(100 \mu \mathrm{g})$, synthetic $\left[\mathrm{Arg}^{8}\right]-\mathrm{LHRH}(25 \mu \mathrm{g})$ or $\mathrm{P}_{4}(1.0 \mathrm{mg})$ was injected at $45 \mathrm{hr}$ after Pt implantation. Both $\mathrm{LH}$ and LHRH injections induced ovulations at the rate of 70 and $80 \%$, respectively. Conversely, $\mathrm{P}_{4}$ injection (after Pt treatment) failed in inducing ovulation in the majority of hens examined (ovulation, $27 \%$ ). The same of ovine $\mathrm{LH}$, LHRH and $\mathrm{P}_{4}$ induced ovulations at the rates of 70,80 and $75 \%$, respectively, when they were injected $13.5 \mathrm{hr}$ after $\mathrm{C}_{2}$ ovulation in hens without $\mathrm{Pt}$ treatment. These results suggest that exogenous $\mathrm{Pt}$ may exert its inhibitory effect on the hypothalamus or other regions of the CNS implicated with regulation of the preovulatory LH release. The ovulation-induction time in hens pretreated with $\mathrm{Pt}$ was shorter in response to $\mathrm{LH}(6.0 \mathrm{hr})$ or LHRH $(4.7$ hr) injection when compared to hens without $\mathrm{Pt}$ treatment $(8.8 \mathrm{hr})$. This was reflected upon higher concentrations of plasma $\mathrm{P}_{4}$ in Pt-treated hens.

\section{Acknowledgement}

The authors would like to express their gratitude to Dr. R. J. ETches (University of 
Guelph) for his helpful comments on this manuscript and to Dr. S. RAIPI (NIMADD) for providing us with ovine LH. This study was supported partly by Grants-in-Aid (58360028 and 60304036) to K. Shimada from the Ministry of Education, Science and Culture of Japan.

\section{References}

1) Wilson, S. C. and P. J. Sharp (1975) Changes in plasma concentrations of luteinizing hormone after injection of progesterone at various times during the ovulatory cycle of the domestic hen (Gallus domesticus), J. Endocrinol., 67: 59 70.

2) Wilson, S. C. and P. J. Sharp (1976) The effects of progesterone on oviposition and ovulation in the domestic fowl (Gallus domesicus), Br. Poult. Sci., 17: 163 173.

3) Etches, R. J. and F. J. Cunningham (1976) The interrelationship between progesterone and luteinizing hormone during the ovulation cycle of the hen (Gallus domesticus), J. Endocrinol., 71: $51 \sim 58$.

4) RALPh, C. L. and R. M. FRAPS (1959) Effect of hypothalamic lesions on progesterone-induced ovulation in the hen, Endocrinology, 65: 819 824.

5) Ralph, C. L. and R. M. Fraps (1960) Induction of ovulation in the hen by injection of progesterone into the brain, Endocrinology, 66: 269 272.

6) Fraser, H. M. and P. J. Sharp (1978) Prevention of positive feedback in the hen (Gallus domesticus) by antibodies to luteinizing hormone releasing hormone, J. Endocrinol., 76: 181 182.

7) Johnson, A. L. and A. van Tienhoven (1980) Hypothalamo-hypophysial sensitivity to hormones in the hen. I. Plasma concentrations of LH, progesterone, and testosterone in response to central injections of progesterone and R 5020, Biol. Reprod., 23: 910 917.

8) Kamiyoshi, M. and K. TanaKa (1984) Changes in plasma concentrations of LH and ovarian hormones following injections of PMSG in laying hens, Jpn. Poult. Sci., 21: 265 266.

9) Rothchild, I. and R. M. Fraps (1949) The induction of ovulating hormone release from the pituitary of the domestic hen by means of progesterone, Endocrinology, 44: 141 149.

10) Shimada, K. and I. Asai (1978) Uterine contraction during the ovulatory cycle of the hen, Biol. Reprod., 19: 1057 1062.

11) Warren, D. C. and H. M. Scott (1935) The time factor in egg formation, Poult. Sci., 14: 195 207.

12) Imai, K. and A. V. Nalbandov (1978) Plasma and follicular steroid levels of laying hens after the administration of gonadotropins, Biol. Reprod. 19: 779 784.

13) Shodono, M., T. Nakamura, Y. Tanabe and K. Wakabayashi (1975) Simultaneous determinatious determinations of oestradiol-17 $\beta$, progesterone and luteinizing hormone in the plasma during the ovulatory cycle of the hen, Acta Endocrinol., 78: 565 573.

14) Tanabe, Y., T. Nakamura, K. Fujioka and O. Doi (1979) Production and secretion of sex steroid hormones by the testes, the ovary, and the adrenal glands of embryonic and young chikens (Gallus domesticus), Gen. Comp. Endocrinol., 39: 26 33.

15) Hattori, M. and K. WaKabayashi (1979) Isoelectric focusing and gel filtration studies on the heterogeneity of avian pituitary luteinizing hormone, Gen. Comp. Endocrinol., 39: 215 221.

16) Johnson, A. L., P. A. Johnson and A. van Tienhoven (1984) Ovulatory response, and plasma concentrations of luteinizing hormone and progesterone following administration of synthetic mammalian or chiken luteinizing hormone-releasing hormone relative to the first or second ovulation in the sequence of the domestic hen, Biol. Reprod., 31: 646 655.

17) Fraps, R. M. (1955) Progress in the Physiology of Farm Animals, vol. 2. (J. Hammond, ed.): p. 661 740. Butterworths Scientific Publications, London.

18) Kawashima, M., M. Kamiyoshi and K. Tanaka (1980) Relationship between the changes in cytoplasmic progesterone receptor concentration and in nuclear progesterone binding sites in the hen hypothalamus and pituitary during the ovulatory cycle, Endocrinol. Japon, 27: 667 670.

19) Kawashima, M., M. Kamiyoshi and K. Tanaka (1981) Progesterone receptors in hypothalamus and pituitary of the during the ovulatory cycle. In: Advances in Physiological Sciences (PETHEs, G., P. Peczely and P. Rudas eds. ): vol. 32, pp. 35-42, Akademiai Kiado, Budapest.

20) Imai, K. (1973) Effects of avian and mammalian pituitary preparation on induction of ovulation in the domestic fowl, Gallus domesticus, J. Reprod. Fert., 33: 91 98.

21) Johnson, A. L. (1983) Effects of ovine LH on steroid secretion and ovulation relative to stage of the sequence, and in PMSG-primed hens, Poult. Sci., 62: 1444. 
22) Bahr, J. M. and A. L. Johnson (1984) Regulation of the follicular hierarchy and ovulation, J. Expt. Zool., 232: 495 500.

23) Johnson, P. A., S. S. Palmer and J. M. Bahr (1985) Hormone stimulable adenyl cyclase and steroid concentration of follicles of the pregnant mare's serum gonadotropin-treated hens, Biol. Reprod., 32: $828 \sim 833$.

\title{
プロゲステロン持続性投与の排卵抑制効果
}

\author{
斎藤 昇・都築紀理・島田清司
}

名古屋大学農学部, 名古屋市 464

ニワトリの $\mathrm{LH}$ 分泌に対するプロジェステロン $\left(\mathrm{P}_{4}\right)$ の正のフィードバック作用については多数の報告がある が負のフィードバック作用についての研究はほとんどな されていない。従って, 本研究は, 人為的に血中 $\mathrm{P}_{4}$ 濃 度を高濃度に維持し, 次卵排卵の 抑制効果と血中 $\mathrm{LH}$, $\mathrm{P}_{4}$, テストステロン $(\mathrm{T})$ 打よびェストラジオール $\left(\mathrm{E}_{2}\right)$ 濃度におよぼす影響と, さらに，視休下部一下垂体前葉 一卵巣軸のどのレベルで抑制作用が起こるのかを検討す るために行なった。

10-14 ケ月齢のニワトリ（1.55-2.21 kg）を個別ケー ジに入れて, 飼料と水は自由掑取, 照明は 14 時間/日の もとで飼育した。放卵記録装置により産卵時刻を毎日記 録し，クラッチサイズが5-8 卵からなり，クラッチ間休 産日が一日で比較的規則正しい産卵パターンを示す二ワ トリを実験に使用した。

クラッチ第 2 卵 $\left(\mathrm{C}_{2}\right)$ の排卵後 1.5 時間にサイラスチ ックチューブ（長さ $5 \mathrm{~cm}$, 内径 $2.64 \mathrm{~mm}$ ) に充填したプ ロゲステロン粉末 $(\mathrm{Pt}, 2$ 本/ 1 羽)をニワトリの腹部皮 下に植え込んだ。排卵時刻は全ての実験に打いて予想さ れる時刻の 2-4 時間後に剖検を行ない排卵した卵の卵管 内位置から推定した。

実験 $1 . P \mathrm{P}$ 処理後 45 時間と 73 時間に二ワトリを殺 乙排卵時刻, 血中ホルモン動態, 卵胞重量を測定した。 実験 2. 処理群には Pt 処理後 45 時間にヒツジ LH (100 $\mu \mathrm{g}) を$ ，未処理群には比較としてPt 処理しない二ワト リの $\mathrm{C}_{2}$ 排卵後 13.5 時間 $\left(\mathrm{C}_{3}\right.$ 排卵前 12 時間) に $\mathrm{LH}$ $(100 \mu \mathrm{g})$ を投与した。実験 3 と 4 では実験 2 と同様な 時間に合成 $\left[\mathrm{Arg}^{8}\right]-\mathrm{LHRH}(25 \mu \mathrm{g})$ あるいは $\mathrm{P}_{4}(0.1$ $\mathrm{mg}$ )をそれぞれ投与した。

採血は上腕静脈にカテーテルを取り付け, 実験 1 では $\mathrm{Pt}$ 処理後 $0,2,4,6$ と 45 時間に, 実験 $2,3,4$ では $\mathrm{Pt}$ 処理, 未処理群とも $\mathrm{LH}, \mathrm{LHRH}$ あるいは $\mathrm{P}_{4}$ 投与の 0 ,
1，2，3，4 時間に連続的に行ない，血漿を $-20^{\circ} \mathrm{C}$ に保存 した。 $\mathrm{LH}, \mathrm{P}_{4}, \mathrm{~T}$ および $\mathrm{E}_{2}$ の血中濃度はラジォイム ノアッセイにより行なった。

$\mathrm{Pt}$ 処理により血中 $\mathrm{P}_{4}$ 濃度はすみやかに増加し 45 時 間にわたって高い濃度が維持された。LH 濃度も植え込 又後 4 時間までは増加したが，その後は植え込又前の值 より低下した。 $\mathrm{T}$ と $\mathrm{E}_{2}$ 濃度も $\mathrm{LH}$ 濃度と同様な変化で あったが有意差が見られたのは植え込及後 45 時間のみ で最低濃度となった時であった。また Pt 処理により次 卵排卵は 41 時間以上蒝延した。すなわち,この間には, もし $\mathrm{Pt}$ 処理しなければ次卵 $\left(\mathrm{C}_{3}\right)$ 排卵はもとより $\mathrm{C}_{4}$ 排 卵も起こったはずである。

$\mathrm{Pt}$ 処理後の 視床下部一下垂体前葉一卵巣軸の反応性 を検討するために $\mathrm{Pt}$ 処理後 45 時間に LH, LHRH あ るいは $\mathrm{P}_{4}$ を投与した結果，前二者に対して排卵は 70 , $80 \%$ の率で誘起されたが $\mathrm{P}_{4}$ に対しては $27 \%$ 誘起され たにすぎなかった。なお， $\mathrm{Pt}$ 末処理群ではそれぞれ70, 60 ，および $78 \%$ の排卵誘起率であった。また，排卵は Pt 処理群の方が末処理群より LH および LHRH 投与後早 く誘起された。

$\mathrm{Pt}$ 処理後の $\mathrm{LH}$ あるい: LHRH 投与に対し血中 $\mathrm{P}_{4}$ 濃度は未処理群よりも早く増加し，測定期間（4時間） 全体にわたって高い值に維持された。また，Pt好理群の 卵胞重量は未処理群より大きかった。

以上の結果, $\mathrm{Pt}$ 処理によって排卵が誘起されるのは $\mathrm{P}_{4}$ が視床下部を含む脳神経系に作用して LHRH 放出を 抑制しているからであろらと考えられた。また $\mathrm{Pt}$ 処理 後による排卵反応性（排卵誘起率, 排卵誘起時間) の増 加は, 処理後の卵栄の反応性 $\left(\mathrm{P}_{4}\right.$ 分泌) の増加に関連し ていると考えられた。

（家禽会誌， 23 巻， 211～221，1986） 